\title{
Zoo-heleoplankton structure in three artificial ponds of North-eastern Argentina
}

\author{
S. M.Frutos ${ }^{1,2} \&$ R. Carnevali ${ }^{2}$ \\ 1. Centro de Ecología Aplicada del Litoral (CONICET). C. C. 291, 3400, Corrientes, Argentina; \\ margaritafrutos_587@hotmail.com \\ 2. Universidad Nacional del Nordeste (UNNE). Av. Libertad 5500, 3400, Corrientes, Argentina; \\ romicarnevali@hotmail.com
}

Received 20-IV-2007. Corrected 30-VI-2008. Accepted 31-VII-2008.

\begin{abstract}
The aim of the present study was to compare the abundance and species richness of zoo-heleoplankton bigger than $53 \mu \mathrm{m}$ in an annual cycle under similar climate conditions in three artificial ponds, in order to observe the changes during an annual cycle. Samples were taken monthly from June 1993 to July 1994 in Corrientes, Argentina. The first pond (A) was covered an $80 \%$ by Eichhornia crassipes (Mart.), the second one (B) with bloom of Microcystis aeruginosa (Kurtzing) and the last one (C) with organic matter deposited in the bottom. The water was more acidic at pond A, and the water at pond B contained more dissolved oxygen concentration than the water at the other two ponds. The zoo-heleoplankton densities varied between 20-1728 ind. $1^{-1}$ at pond A, 42-4082 ind. $1^{-1}$ at pond B and 148-2447 ind. $1^{-1}$ at pond C. The maximum zoo-heleoplankton abundance was found in the pond with cyanobacteria bloom during Autumn 1994 and the minimum abundance was found in the one with a predominance of E. crassipes. The rank of species richness was pond $\mathrm{A}>$ pond $\mathrm{B}>$ pond C. Rotifera was the most abundant group in pond A whereas the larval stages of Copepoda were abundant in the other two ponds. Anuraeopsis navicula Rousselt 1910 was the dominant population in the pond with macrophytes prevalence. Brachionus calyciflorus Pallas 1776 and larval stage of Copepoda had variable proportions in the pond with cyanobacteria bloom. Thermocyclops decipiens (Kiefer 1929) was present during the annual cycle only in the pond with organic matter deposited in the bottom. The succession of taxa was observed in the pond with coverage of aquatic macrophytes and with cyanobacteria bloom. Differences in species richness and low similarity in zoo-heleoplankton between ponds were determined by differences in the quality of the water in relation to the presence of macrophytes, cyanobacteria, organic matter deposited in the bottom and fish predation. Multiple regression analysis (stepwise) revealed that water transparency, dissolved oxygen and conductivity were the environmental variables that explained more than $42 \%$ of variability in the abundance of the dominant species. Rev. Biol. Trop. 56 (3): 1135-1147. Epub 2008 September 30.
\end{abstract}

Key words: Zoo-heleoplankton, abundance, richness, aquatic macrophytes, cyanobacteria, organic matter, fish.

In the province of Corrientes (Argentina), there are lakes, ponds and marshes with particular environmental conditions that change due to their macrophytes coverage, water transparency and the organic matter deposited in the bottom. Among the macrophytes, E. crassipes is the most important in terms of coverage, biomass and productivity (Carignan \& Neiff 1992). In these conditions, few euplanktonic populations were developed in relation to light limitation and this could thus explain the scarcity abundance of phytoplankton transferable to zooplankton communities (Frutos 2003). In water rich in organic matter originated from decomposition of aquatic macrophytes, with high lignin content and under low $\mathrm{N}: \mathrm{P}$ ratio (Casco et al. 2003), differences in the composition and structure of the zooplankton are predictable. Rotifera is the dominant group in water with cyanobacteria bloom (Starkweather 
\& Kellar 1983, González de Infante 1988, Rocha et al. 2002, Frutos 1998, Poi de Neiff et al. 1999, Neiff et al. 2002, Pecorari et al. 2006). At present, seasonal comparisons of zoo-heleoplankton in the same climate but with different limnologic conditions have not been carried out in the Northeast of Argentina.

The aim of the present study was to compare abundance and species richness of zooheleoplankton bigger than $53 \mu \mathrm{m}$ in an annual cycle under similar climate conditions in three artificial ponds. The first one covered with $E$. crassipes, the second one with $M$. aeruginosa bloom and the third pond with organic matter deposited in the bottom.

\section{MATERIALS AND METHODS}

The study was carried out in the Centro de Ecología Aplicada del Litoral (Corrientes, Argentina; $27^{\circ} 28^{\prime} \mathrm{S}$; $58^{\circ} 44^{\prime} \mathrm{W}$ ) in three openair artificial ponds (A, B and C), filled with water from different natural lakes and maintained by rain. The size of each artificial pond was $10 \mathrm{~m}$ length, $2 \mathrm{~m}$ width and $1.7 \mathrm{~m}$ depth. In pond $A$ with aquatic macrophytes, two sampling areas were found, a vegetated area (A) covered an $80 \%$ with E. crassipes and a free water area (A'). Pond B with bloom of $M$. aeruginosa and $\mathrm{C}$, without macrophyte coverage, were characterized by having organic matter particles and dissolved matter of vegetal origin deposited in the bottom. The physical and chemical variables measured in the ponds were water transparency (Secchi disk), electrical conductivity (conductometer YSI M57), water temperature, dissolved oxygen (Oximeter potentiometer $330 \mathrm{WTW})$ and $\mathrm{pH}(\mathrm{pH}$ meter). Samples were taken monthly during an annual cycle from June 1993 to July 1994, having previously determined the minimum sampling area (8.5 liters, curve species-area) according to Modenutti \& Balseiro (1995). Samples were filtered through a plankton net of $53 \mu \mathrm{m}$ mesh size. They were preserved with a $4 \%$ formaldehyde solution. The vegetated area (A) was sampled in a hydrographic bottle $(10 \mathrm{~cm}$ diameter and $1 \mathrm{~m}$ length) according to Boltovskoy
(1981). In ponds B and C, without macrophytes, the samples were taken with a centrifugal pump. In addition to that, the capture of predator fish was carried out in each pond during May 1994. The count of zooplankters was carried out according to José de Paggi \& Paggi (1995). The abundance of zoo-heleoplankton (ind. $1^{-1}$ ) and species richness (number of species) were estimated. A nonparametric analysis of variance (Kruskal-Wallis test) with Dunn's multiple comparison post-test was used to test for significant differences between ponds. In pond $\mathrm{A}$, species richness among the vegetated area and free water was compared using MannWhitney U-test (Sokal \& Röhlf 1979). The similarity between zoo-heleoplankton communities among the three artificial ponds was determined according to Jaccard index (Sokal \& Röhlf 1979), and it was expressed in percentages. The relationship between the most abundant populations and environmental variables (temperature, water transparency, $\mathrm{pH}$, conductivity, dissolved oxygen) were estimated by multiple regressions analysis (stepwise), after normalization of the zoo-heleoplankton density data $(\log (\mathrm{x}+1))$ and environmental variables. Statistical analysis was done using Stat Graphic Plus, version 5.1.

\section{RESULTS}

In pond $\mathrm{A}, \mathrm{pH}$ ranged between acidic to basic, electrical conductivity was higher than at the other two ponds and, dissolved oxygen concentration was variable with values next to zero (Table 1). In pond $\mathrm{B}$, high concentrations of dissolved oxygen and basic $\mathrm{pH}$ were measured. In pond $\mathrm{C}$, light permeability was low, dissolved oxygen concentration was variable and $\mathrm{pH}$ was basic. Electrical conductivity and dissolved oxygen had high significant differences among the three artificial ponds (Kruskal-Wallis; Table 2) and, water transparency and $\mathrm{pH}$ had less significant differences (Table 2).

Significant differences in the abundance and species richness were found among the artificial ponds (Table 2). In pond A, the abun- 
TABLE 1

Means and ranges of physical and chemicals variables of water

\begin{tabular}{|c|c|c|c|c|c|c|}
\hline Ponds & $\begin{array}{c}\text { Statistics of } \\
\text { samples }\end{array}$ & $\begin{array}{c}\text { Water } \\
\text { temperature } \\
\left({ }^{\circ} \mathrm{C}\right)\end{array}$ & $\begin{array}{c}\text { Transparency } \\
\text { (Secchi, m) }\end{array}$ & $\begin{array}{l}\text { Dissolved } \\
\text { oxygen } \\
\left(\mathrm{mg} .1^{-1}\right)\end{array}$ & $\mathrm{pH}$ & $\begin{array}{l}\text { Conductivity } \\
\left(\mu \mathrm{S} . \mathrm{cm}^{-1}\right)\end{array}$ \\
\hline A & $\begin{array}{c}\text { X } \\
(\mathrm{R}) \\
\text { C.V. }(\%)\end{array}$ & $\begin{array}{c}22.7 \\
(11.5-30) \\
26\end{array}$ & n.a. & $\begin{array}{c}1.5 \\
(0.6-3.4) \\
87\end{array}$ & $\begin{array}{c}7.7 \\
(5.4-8.1) \\
8\end{array}$ & $\begin{array}{c}321 \\
(250-440) \\
18\end{array}$ \\
\hline$A^{\prime}$ & $\begin{array}{c}\text { X } \\
(\mathrm{R}) \\
\text { C.V. }(\%)\end{array}$ & $\begin{array}{c}22.3 \\
(12-30) \\
26\end{array}$ & $\begin{array}{c}1.39 \\
(0.64-1.8) \\
72\end{array}$ & $\begin{array}{c}2.5 \\
(0.7-4) \\
60\end{array}$ & $\begin{array}{c}7.7 \\
(5.4-8.2) \\
8.1\end{array}$ & $\begin{array}{c}324 \\
(190-440) \\
19\end{array}$ \\
\hline B & $\begin{array}{c}\text { X } \\
(\mathrm{R}) \\
\text { C.V. }(\%)\end{array}$ & $\begin{array}{c}22.5 \\
(12.3-31) \\
25\end{array}$ & $\begin{array}{c}0.67 \\
(0.43-1.15) \\
31\end{array}$ & $\begin{array}{c}11.8 \\
(6.8-15.6) \\
21\end{array}$ & $\begin{array}{c}9.03 \\
(7.7-10.6) \\
14\end{array}$ & $\begin{array}{c}116 \\
(100-140) \\
10\end{array}$ \\
\hline $\mathrm{C}$ & $\begin{array}{c}\text { X } \\
(\mathrm{R}) \\
\text { C.V. }(\%)\end{array}$ & $\begin{array}{c}21.8 \\
(11-31) \\
25\end{array}$ & $\begin{array}{c}0.49 \\
(0.24-0.65) \\
32\end{array}$ & $\begin{array}{c}8.88 \\
(6-12.6) \\
31\end{array}$ & $\begin{array}{c}9.02 \\
(8.6-9.67) \\
5\end{array}$ & $\begin{array}{c}164 \\
(131-200) \\
14\end{array}$ \\
\hline
\end{tabular}

A, B and C: artificial ponds. X: arithmetic mean, (R): variation range, C.V.: variation coefficient, n.a.: not available, n: data number in each pond $(\mathrm{n}=29)$.

TABLE 2

Non-parametric analysis of variance (Kruskal-Wallis) and Dunn's comparison post test between environmental variables, zoo-heleoplankton density and species richness

\begin{tabular}{|c|c|}
\hline \multicolumn{2}{|c|}{ Environmental variables of $\mathrm{A}, \mathrm{B}, \mathrm{C}$ ponds } \\
\hline Electrical conductivity & $\begin{array}{l}\mathrm{A} \text { and } \mathrm{B}^{* * *} \mathrm{p}<.001 \\
\mathrm{~A} \text { and } \mathrm{C}^{* * *} \mathrm{p}<.001 \\
\mathrm{~B} \text { and } \mathrm{C}^{* * *} \mathrm{p}<.001\end{array}$ \\
\hline Dissolved oxygen & $\begin{array}{c}\mathrm{C} \text { and } \mathrm{B}^{*} \mathrm{p}<.05 \\
\mathrm{C} \text { and } \mathrm{A}^{* * *} \mathrm{p}<.001 \\
\mathrm{~B} \text { and } \mathrm{A}^{* * *} \mathrm{p}<.001\end{array}$ \\
\hline Water transparency (Secchi) & $\begin{array}{c}A \text { and } B^{*} p<.05 \\
A \text { and } C^{* *} p<.01\end{array}$ \\
\hline $\mathrm{pH}$ & $\mathrm{A}$ and $\mathrm{B}^{*} \mathrm{p}<.05$ \\
\hline \multicolumn{2}{|c|}{ Zoo-heleoplankton } \\
\hline Abundance (ind. $1^{-1}$ ) & $\mathrm{A}$ and $\mathrm{C}^{*} \mathrm{p}<.05$ \\
\hline Species richness (species number) & $\begin{array}{l}\mathrm{A}^{\prime} \text { and } \mathrm{C}^{* * *} \mathrm{p}<.001 \\
\mathrm{~B} \text { and } \mathrm{C}^{* * *} \mathrm{p}<.001\end{array}$ \\
\hline
\end{tabular}

Statistical significance: $* * *$ high significative, $* *$ significative, ${ }^{*}$ low significative.

dance (Fig. 1) increased in Spring 1993, in Summer and during the first days of Autumn 1994. Rotifera was the most abundant group in free water and larval stages of copepods were dominant in the vegetated area. Among the dominant taxa in the vegetated area with
E. crassipes, Bdelloidea was present during all the study period, Polyarthra sp. was found in low abundance whereas Mesocyclops meridianus (Kiefer 1926) was frequent. High species richness (51 species) was registered in this area. A. navicula was abundant in free water in 
coincidence with the presence of a zooplankter predator (Asplanchna sp.) and oxygen concentrations next to zero. Filinia terminalis (Plate 1886 ) and F. saltator (Gosse 1886) were subdominant in Summer 1994.

In pond $\mathrm{B}$, high abundance (4082 ind. $\mathrm{l}^{-1}$ ) was found in Autumn 1994 (Fig. 2). Copepoda, fundamentally represented in larval stages, was the most abundant group (Fig. 2). B. calyciflorus and copepods larval stages alternated their dominance, Polyarthra sp. and Moina minuta (Hansen 1890) followed in abundance. The species richness was low (14 species).
In pond $\mathrm{C}$, low abundance was registered in Winter 1993-94 and November 1993, although it increased considerably in the Spring-Summer period of both years (Fig. 3). Copepoda was the most abundant group with high density of larval stages (Fig. 3). T. decipiens was the only population present. At the same time, other predators such as Acarina were also observed. In comparison with the other two ponds, lower species richness was found (4 species, Table 4). Stepwise multiple regression analysis revealed that water transparency and dissolved oxygen concentrations explained $49 \%$ of the

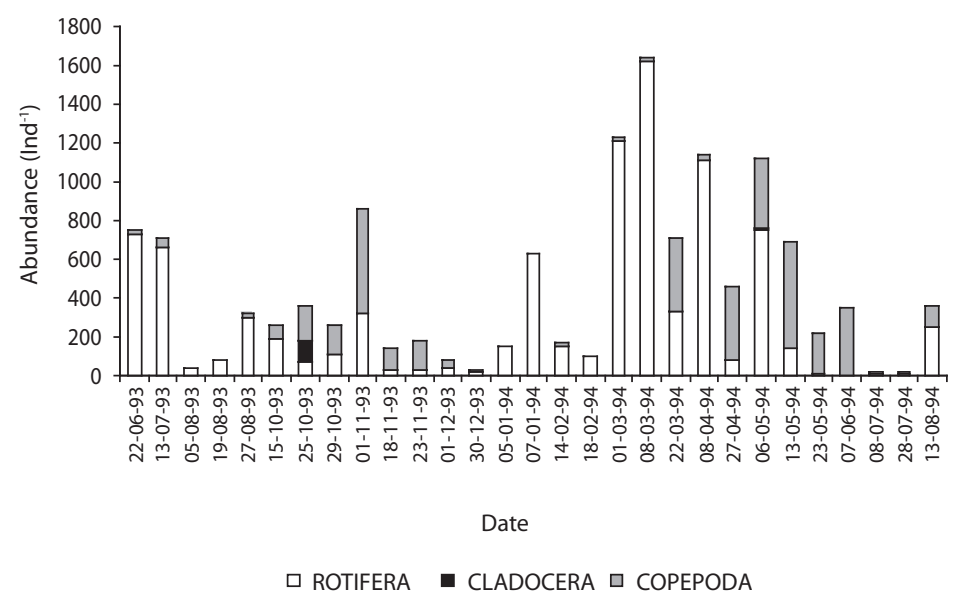

Fig. 1. Annual variation of zoo-heleoplankton abundance in pond A with E. crassipes.

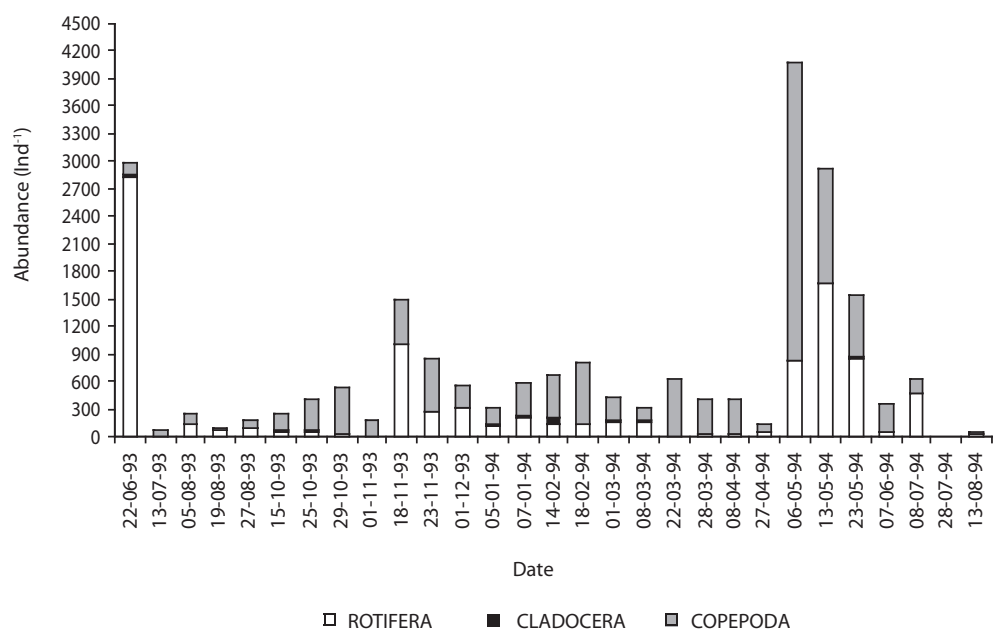

Fig. 2. Annual variation of zoo-heleoplankton abundance in pond B with M. aeruginosa. 


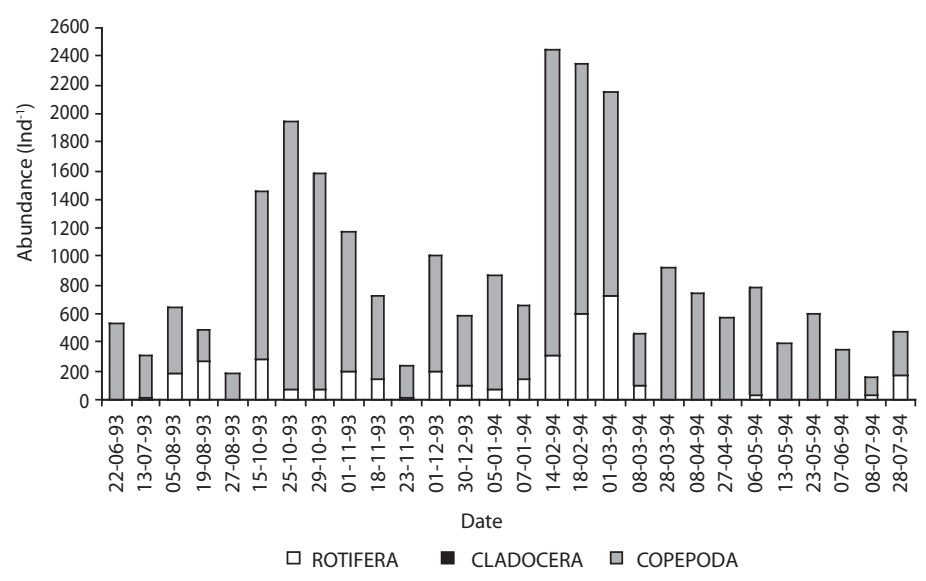

Fig. 3. Annual variation of zoo-heleoplankton abundance in pond $\mathrm{C}$ with organic matter deposited in the bottom.

TABLE 3

Multiple regression analysis (stepwise) between most abundant population of zoo-heleoplankton and environmental variables

\begin{tabular}{|c|c|c|c|}
\hline Environmental variables & Estimate & Standard error & $\mathrm{r}^{2}$ ajusted $(\%)$ \\
\hline \multicolumn{4}{|l|}{ Anuraeopsis navicula } \\
\hline $\begin{array}{l}\text { Constant } \\
\text { Water transparency } \\
\text { Dissolved oxygen }\end{array}$ & $\begin{array}{c}0.618483 \\
3.5237 \\
-1.07881\end{array}$ & $\begin{array}{c}0.52176 \\
1.06356 \\
0.360933\end{array}$ & $\begin{array}{c}0.00 \\
42.15 \\
49.44\end{array}$ \\
\hline \multicolumn{4}{|l|}{ Brachionus calyciflorus } \\
\hline $\begin{array}{l}\text { Constant } \\
\text { Water transparency } \\
\text { Conductivity }\end{array}$ & $\begin{array}{c}6.741 \\
-2.7288 \\
-2.13937\end{array}$ & $\begin{array}{c}1.39481 \\
1.32493 \\
0.698731\end{array}$ & $\begin{array}{c}0.00 \\
35.71 \\
39.29\end{array}$ \\
\hline \multicolumn{4}{|l|}{ Thermocyclops decipiens } \\
\hline $\begin{array}{l}\text { Constant } \\
\text { Water transparency } \\
\text { Conductivity }\end{array}$ & $\begin{array}{c}5.23978 \\
-4.68322 \\
-1.33\end{array}$ & $\begin{array}{c}1.08038 \\
1.02626 \\
0.541219\end{array}$ & $\begin{array}{c}0.00 \\
51.72 \\
55.78\end{array}$ \\
\hline
\end{tabular}

variability in abundance of $A$. navicula (Table 3). Transparency and electrical conductivity of water explained $39 \%$ of variability in the abundance of B. calyciflorus and $56 \%$ of variability in the abundance of T. decipiens.

In the pond with E. crassipes, differences in abundance between the vegetated area and free water were found (M-W U-test $=134, \mathrm{p}<$ .01 ), although no significant differences of species richness were found between the vegetated area and free water $(\mathrm{M}-\mathrm{W}$ U-test $=114, \mathrm{p}=$ .13). Among Rotifera, Bdelloidea was the most abundant taxa in the vegetated area, whereas A. navicula was the most abundant in free water. Polyarthra sp. was frequent in artificial ponds A and B. Among Crustacea, M. minuta was frequent within Cladocera in the pond with cyanobacteria bloom and M. meridianus (Copepoda) was frequent in the floating macrophytes area. T. decipiens (Copepoda) was important in the pond with organic matter deposited in the bottom (Table 4).

The pattern of succession was observed in the pond with aquatic macrophytes where the 
TABLE 4

The most frequent taxa of zoo-heleoplankton

\begin{tabular}{|c|c|c|c|c|}
\hline Taxa / samples of ponds & $A^{\prime}$ & A & $\mathrm{B}$ & $\mathrm{C}$ \\
\hline \multicolumn{5}{|c|}{ ROTIFERA } \\
\hline Bdelloidea & $\mathrm{X}$ & XXX & & \\
\hline Anuraeopsis navicula Rousselt 1910 & $\mathrm{X}$ & $\mathrm{X}$ & $\mathrm{X}$ & \\
\hline Asplanchna sieboldi (Leydig 1854) & $\mathrm{X}$ & $\mathrm{X}$ & & \\
\hline Beauchampiella eudactylota (Gosse 1886) & & $\mathrm{XX}$ & & \\
\hline Brachionus calyciflorus Pallas 1776 & $\mathrm{X}$ & $\mathrm{X}$ & $\mathrm{XX}$ & $\mathrm{XX}$ \\
\hline Brachionus dolabratus Harring 1915 & & $\mathrm{X}$ & $\mathrm{X}$ & \\
\hline Brachionus urceolaris (O. F. Müller 1773) & & $\mathrm{X}$ & & \\
\hline Cephalodella sp. & & $\mathrm{X}$ & & \\
\hline Cephalodella gibba (Ehrb. 1838) & & $\mathrm{X}$ & & \\
\hline Colurella sp. & $\mathrm{X}$ & $X$ & $\mathrm{X}$ & \\
\hline Colurella oblonga oblonga Donner 1943 & & $\mathrm{XX}$ & & \\
\hline Colurella obtusa (Gosse 1886) & $\mathrm{X}$ & $\mathrm{X}$ & & \\
\hline Conochilus coenobasis Skorikov 1914 & & $\mathrm{X}$ & & \\
\hline Dipleuchlanis propatula (Gosse 1886) & $X$ & $\mathrm{XX}$ & & \\
\hline Euchlanis sp. & & $\mathrm{X}$ & & \\
\hline Filinia saltator (Gosse 1886) & $\mathrm{X}$ & $\mathrm{X}$ & $\mathrm{X}$ & \\
\hline F. terminalis (Plate 1886) & $\mathrm{X}$ & $\mathrm{X}$ & & \\
\hline Keratella cochlearis (Gosse 1851) & $\mathrm{X}$ & & & \\
\hline K. lenzi (Hauer 1953) & $\mathrm{X}$ & & & \\
\hline Lecane (M) sp. & $\mathrm{X}$ & $\mathrm{X}$ & & \\
\hline Lecane arcula (Harring 1914) & $\mathrm{X}$ & $\mathrm{X}$ & & \\
\hline Lecane cornuta (O. F. Müller 1786) & & $X$ & & \\
\hline L. curvicornis (Murray 1913) & $X$ & $X$ & & \\
\hline Lecane sp. & & $\mathrm{X}$ & & \\
\hline Lecane closterocerca (Schmarda 1859) & $\mathrm{X}$ & $\mathrm{X}$ & & \\
\hline Lecane hamata (Stockes 1896) & $\mathrm{X}$ & & $\mathrm{X}$ & \\
\hline L. ludwigi (Eckstein 1883) & & $\mathrm{X}$ & & \\
\hline L. papuana (Murria 1913) & $\mathrm{X}$ & $\mathrm{X}$ & & \\
\hline L.(M) quadridentata (Ehrb. 1832) & $\mathrm{X}$ & $\mathrm{X}$ & & \\
\hline L. stichaea Harring 1913 & $\mathrm{X}$ & $\mathrm{X}$ & & \\
\hline Lepadella sp. & $X$ & $X$ & & \\
\hline Lepadella sp.1 & & $\mathrm{X}$ & & \\
\hline L. cf. donneri Koste 1972 & & $\mathrm{X}$ & & \\
\hline Monommata sp. & & $X$ & & \\
\hline Mytilina sp. & $\mathrm{X}$ & $\mathrm{X}$ & & \\
\hline Mytilina crassipes (Lucks 1912) & $\mathrm{X}$ & $\mathrm{XX}$ & & \\
\hline
\end{tabular}


TABLE 4 (Continued)

The most frequent taxa of zoo-heleoplankton

\begin{tabular}{|c|c|c|c|c|}
\hline Taxa / samples of ponds & $A^{\prime}$ & A & B & $\mathrm{C}$ \\
\hline Polyarthra sp. & $\mathrm{X}$ & $\mathrm{XX}$ & $\mathrm{XX}$ & \\
\hline Ptygura sp. & & & $\mathrm{X}$ & \\
\hline Scaridium longicaudum (O. F. Müller 1786) & & $\mathrm{X}$ & & \\
\hline Squatinella sp. & $\mathrm{X}$ & & & \\
\hline Squatinella cf. mutica (Ehrb. 1832) & & & $\mathrm{X}$ & \\
\hline Testudinella patina f. intermedia Anderson 1889 & & $\mathrm{X}$ & & \\
\hline Trichocerca sp. & $\mathrm{X}$ & $\mathrm{X}$ & & \\
\hline Trichocerca similis (Wierzejski 1893) & $\mathrm{X}$ & $\mathrm{X}$ & $\mathrm{X}$ & \\
\hline "X" not identified & $\mathrm{X}$ & & & \\
\hline
\end{tabular}

"X" not identified

CLADOCERA

Alona monocantha (Sars 1901)

Alona verrucosa (Sars 1901)

X

$\mathrm{X}$

Alonella sp.

Chydorus pubescens (Sars 1901)

Diaphanosoma birgei Korinek 1980

Disparalona dadayi (Birge 1910)

Dunhevedia odontoplax (Sars 1901)

Echinisca elegans (Sars 1901)

Euryalona occidentalis (Sars 1901)

Ilyocryptus paranaensis Paggi 1989

Ilyocryptus spinifer Herrick 1884

Kurzia cf. latissima (Kurz 1875)

Moina minuta Hansen 1890

Simocephalus vetulus (O. F. Müller 1785)

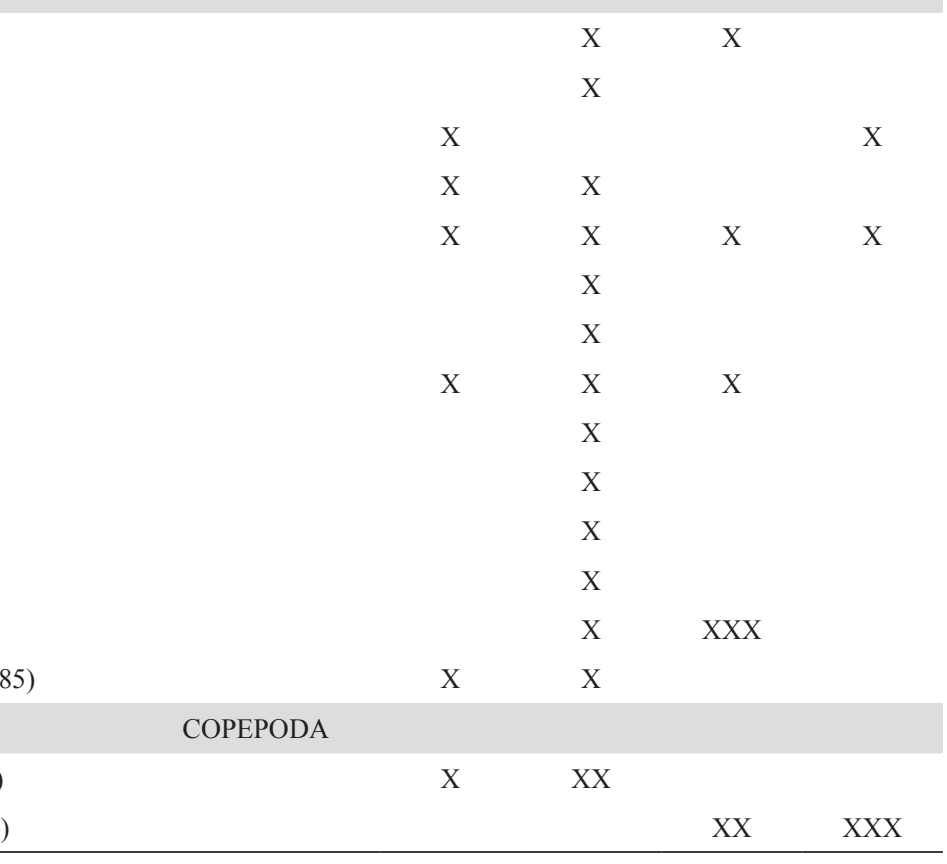

Thermocyclops decipiens (Kiefer 1929)

$\mathrm{x}$ : scarce (25\%), xx: frequent (50\%), xxx: very frequent (>50\%).

different groups of zooplankters were replaced: Anuraeopsis, Mesocyclops larval stage, Filinia and Polyarthra. On the other hand, Anuraeopsis was dominant in Autumn-Winter and larval stage of Copepoda (T. decipiens) in Spring and Summer. In the pond with cyanobacteria bloom, B. calyciflorus and larval stage of cyclopoidea coexisted or alternated their dominance during all the period studied. Only one species of cyclopoid (T. decipiens) was dominant in the pond with organic matter in the bottom.

The rank of species richness was pond $\mathrm{A}>$ pond $\mathrm{B}>$ pond $\mathrm{C}$. Rotifera was the most abundant group in pond A whereas the larval stages of Copepoda were abundant in the other two ponds. 
Similarity of zoo-heleoplankton among the three artificial ponds was low (Jaccard $\mathrm{p}<50 \%$; Table 5). In the same way, no similarity was observed between the two areas of artificial pond A (vegetated area and free water). The composition of fish in the artificial ponds is showed in Table 6 .

TABLE 5

Jaccard Similarity (in percentages) of zoo-heleoplankton taxa in the artificial ponds

\begin{tabular}{|c|cccc|}
\hline & A' $^{\prime}$ & A & B & C \\
\hline A' & $/$ & & & \\
A & 47 & $/$ & & \\
B & 24 & 19 & $/$ & \\
C & 8 & 3 & 12 & $/$ \\
\hline
\end{tabular}

TABLE 6

The fish taxa in ponds

\begin{tabular}{lccc} 
Fishes & A & B & C \\
Astyanax lineatus & $*$ & $* * *$ & $*$ \\
Cichlasoma dimerus & $* *$ & $*$ & $*$ \\
Crenicichla lepidota & $*$ & & \\
Ctenobricon hallen & $* * *$ & $*$ & \\
Cyphocharax sp. & $*$ & & \\
Diapoma terofalis & & $* * *$ & \\
Metynnis mola & $*$ & & \\
Pseudocarynopoma doriai & $*$ & & \\
Prochilodus lineatus & $* *$ & $*$ & $* * *$ \\
Tetranogopterus argenteus & $*$ & & $*$ \\
\hline
\end{tabular}

* 1-10 individual in each pond, ** 11-20,***21-30.

\section{DISCUSSION}

\section{Environmental variables}

Under similar climate conditions, artificial ponds had different limnological characteristics. Acid water and low oxygen concentration in the pond with aquatic macrophytes were related to the reduction process originated by the decomposition of organic matter in the bottom (Poi de Neiff \& Carignan 1997). The alkaline $\mathrm{pH}$ and high oxygen concentration in the pond with cyanobacteria bloom were associated with the photosynthesis of phytoplankton (Wetzel 1975). At the pond with organic matter deposited in the bottom, the fluctuation in water transparency was probably due to the sediment remotion produced by the wind during heavy rains.

\section{Zooplankton structure}

The low zoo-heleoplankton abundance in the pond with E. crassipes was previously reported in the littoral area with a predominance of the same aquatic macrophytes (José de Paggi \& Paggi 2007, Frutos 1993). The low zoo-heleoplankton density was indirectly related to abiotic and biotic condition. The light extinction coefficient among aquatic macrophytes (Poi de Neiff \& Carignan 1997) and the oxygen deficiency producing a stress factor for a decrease in total abundance and an increase in the number of species that adapted to survive hypoxic water characteristics (Poi de Neiff \& Carignan 1997). Moreover the decrease of zoo-heleoplankton density was related to the predation by fish (Corrales de Jacobo \& Canon Veron 1992, Sunaga \& Verani 1997) and was extended to a carnivore rotifer (Asplanchna). Comparatively, the abundance of macroinvertebrate among the roots of E. crassipes was associated with dissolved oxygen and other limnologic characteristics in the Paraná River floodplain (Poi de Neiff \& Carignan 1997). In the same way, seasonality and water temperature did not have an influence in zooheleoplankton abundance.

High zoo-heleoplankton abundance in the pond with cyanobacteria bloom was coincident with what was also recorded in some eutrophic lakes in the Northeast of Argentina (Frutos 1998) and other eutrophic temperate lakes (Erben et al. 2002). Most research on invertebrate density variation in eutrophic lakes abundant in $M$. aeruginosa are related 
to crustacean invertebrate and, occasionally, to the total of zooplankton.

In our study, in both ponds (with macrophytes and organic matter deposited in the bottom) high oxygen concentration favored the increment of abundance. However, low conductivity and transparency values allowed density variation in some populations of zooheleoplankton.

In the three artificial ponds, the variation in densities suggested different patterns of zooplankton abundance associated with trophic and abiotic condition, and with planktivorous fish predation (Lammens et al. 1990, Sendacz et al. 2006). The composition and seasonal variation were related to the increase of dominant species. Although this is important, it was recorded that the Rotifera usually are the most abundant community in tropical and subtropical reservoirs and lakes (Sendazc et al. 2006, José de Paggi \& Paggi 2007), except in the isolate lake from the Paraná River floodplain where Crustacea were the dominant group (Frutos 1993, 1996). Punctually the decrease in zooplankton density in this artificial pond was caused by heavy rains that deposited phytoplankton in the bottom and probably caused sediment remotion.

Different patterns of zooplankton structure were observed in the three ponds with typical environmental characteristics. When Cladocera and Copepoda were scarce, Rotifera was the most important group that showed a similar structure pattern in the temperate lakes (Margalef 1983).

The high density of rotifers in free water of pond with aquatic macrophytes was determined by high water transparency that enhances the development of green algae which are very important for herbivorous zooplankters (Margalef 1983, González de Infante 1988).

The dominance of small-sized zooplankters in the three ponds studied here was due to the selective planktivorus fish predation (Gulati 1990), and to the influence of abiotic condition, which can determine the replacement of large-bodied zooplankton by small-sized zooplankton (Lammens et al. 1990).
The highest abundance of adult copepods and cladocerans appears after fish catch, indicating that a strong predation was caused previously. Dominance of larval copepod stages and cladocerans absence were linked with the relative abundance of predatory fish belonging to Astyanax, Cichlasoma, Ctenobrycon and Diapoma genera, also observed in the Paraná River floodplain by Corrales de Jacobo \& Canon Veron (1992). The invertebrate predation was probably caused by the presence of Acarina and Asplanchna which contributed to the variation of zooplankton density and community structure (Matveev et al. 1989, Matveev et al.1992).

\section{Species richness and similarity}

The high species richness recorded in the pond with aquatic macrophytes was related to their opportunistic characteristics (Lansac-Tôha et al. 2004). On the other hand, the acidity of water with $E$. crassipes does not affect negatively the richness of rotifers in coincidence with what was pointed out by José de Paggi (1996). Comparatively, the higher biodiversity found was related to a higher availability of resources for feeding, refuge, nutrient flux which increases with the geographic extension of lakes and ponds in the subtropical environments (Neiff 2001). Conversely, the scarce number of species richness found in the pond with cyanobacteria bloom was also recorded in some eutrophic lakes (Frutos 1998, José de Paggi \& Paggi 1998, Poi de Neiff et al.1999). A lower number of species in the pond with organic matter deposited in the bottom was found on the annual cycle study.

The high biodiversity with $61 \%$ of littoral species was found among E. crassipes in the water free area, the fact was also mentioned by Poi de Neiff \& Carignan (1997), LansacTôha et al. (2004) and José Paggi \& Paggi (2007). Also, the low species richness in the pond with cyanobacteria bloom was found in the zooplankton of aquatic natural communities (Frutos 1993, Poi de Neiff et al. 1999) of subtropical lakes of Argentina. 
The different environmental characteristics in each pond determined the low similarity of zoo-heleoplankton. Comparatively, the greater difference in the number of species and the scarce number of common species in the three ponds contributed to the fact that there was no similarity in zoo-heleoplankton.

\section{Species dominant}

According to multiple regression analysis the dominant population in artificial ponds was related to some environmental variables such as water transparency, $\mathrm{pH}$, conductivity, and dissolved oxygen. However, the variability of water transparency was similar in all sites. Conversely, low oxygen concentration was prioritized in the pond with aquatic macrophytes and water conductivity in the other two ponds (with cyanobacteria bloom and organic matter).

Respecting the dominant population in the pond with aquatic macrophytes, A. navicula was abundant in free water, which had a large variability of water transparency and low dissolved oxygen concentration. The constant presence of $A$. navicula in free water has been observed in floodplain lakes with E. crassipes prevalence (Frutos 1993).

In the pond with cyanobacteria bloom, the high zoo-heleoplankton abundance was fundamentally related to the increase of $B$. calyciflorus development and the larval stage of $T$. decipiens. The same trend was observed in an eutrophic reservoir with high density and biomass during the dry season, although both species had been low in density (Sendacz et al. 2006). On the other hand, experiments on B. calyciflorus showed that it was unaffected by the blue green toxins and also showed the ability to grow and reproduce on a diet of $M$. aeruginosa (Fulton III \& Paerl 1987). Their experiments on toxicity and herbivory of zooplankters indicate that there are a variety of mechanisms that avoid the consumption of $M$. aeruginosa bloom as resistance to toxic chemicals (B. calyciflorus), chemosensory means (copepods) and inability to consume large colonies such as small cladocerans (Fulton III \& Paerl 1987). However, some herbivorous species of Thermocyclops are capable of maintaining a high population in the presence of cyanobacteria bloom (Rocha et al. 2002). Our study indicated that the high abundance of $B$. calyciflorus was positively influenced by a high concentration of dissolved oxygen and basic $\mathrm{pH}$. Comparatively the increase of B. calyciflorus population was found at similar abiotic range by Mitchell \& Joubert (1986). Also, the low water transparency did not impede the development of the dominant species. Although the higher abundance in Summer was pointed out in eutrophyzed lakes and rivers from Brazil and Argentina (Starkweather \& Kellar 1983, Gulatti 1990, Poi de Neiff et al. 1999, Aoyagui \& Costa Bonecker 2004, Lansac-Tôha et al. 2004).

In the pond with organic matter deposited in the bottom, changes in abundance of $T$. decipiens were due to the same environmental variables indicated for B. calyciflorus. Their varied feeding diets, based mainly on detritus $(>70 \%)$ and other feeding resources (Rietzler \& Espíndola 1998), allowed these populations to survive successfully during the study. Our research ratified the fact that the abundance of $T$. decipiens increases in water with organic matter, alkaline $\mathrm{pH}$ and variable dissolved oxygen concentrations, where a low quotient N: P is found (Casco et al. 2003). Comparatively, the abundance of both species (T. decipiens and B. calyciflorus) in the warm season had been observed in prior researchers on the topic (Nogueira \& Matsumura Tundisi 1996, Lansac Tôha et al. 2004). This cyclopoid pantropical species (Reid 1989) is frequent in eutrophyzed water (Sendacz 1997, Silva \& Matsumura Tundisi 2005, Sendacz et al. 2006) and in floodplain lakes of the Paraná River (Frutos 1993, Campos et al. 1996, Nogueira \& Matsumura-Tundisi 1996, Lansac-Tôha et al. 2004). 


\section{Succession of species}

The pattern of succession was observed in the pond with aquatic macrophytes. Changes between different zooplankton groups were allowed through successive replacements between rotifers and larval stages of copepods. In the pond with cyanobacteria bloom, the alternance of some species characteristics of eutrophic lakes was frequent. Conversely, no succession was observed in the pond with organic matter deposited in the bottom. The variation in dominant species was associated with the variability of limnological condition, supply of food, fish and invertebrate predation, intra-zooplankter predation and the consequent eclosion of resistant egg during rains.

\section{ACKNOWLEDGMENTS}

We thank A. Poi de Neiff for the successful comments that contributed with the present manuscript, M. Canon Veron and Y. Zalocar de Domitrovic for fish and cyanobacteria taxonomic identification repectively and Mind Translations for proofreading the English manuscript.

\section{RESUMEN}

La finalidad del presente estudio fue comparar la abundancia y riqueza de especies del zoo-heleoplancton mayor de $53 \mu \mathrm{m}$, en un ciclo anual bajo condiciones climáticas similares en tres estanques artificiales, con el propósito de observar los cambios durante un ciclo anual. Las muestras fueron tomadas mensualmente desde junio de 1993 hasta julio de 1994 en Corrientes, Argentina. El primer estanque (A) estuvo cubierto un $80 \%$ por $E$. crassipes, el segundo estanque (B) con floraciones de $M$. aeruginosa y el tercer estanque (C) con materia orgánica depositada en el fondo. El agua fue más ácida en el estanque A y tuvo más concentración de oxígeno disuelto en el B. La densidad del zoo-heleoplancton fue variable entre 20-1728 ind. $1^{-1}$ en el estanque A, 42-4082 ind. $1^{-1}$ en el estanque B y 148-2447 ind. $1^{-1}$ en el estanque C. El rango de la riqueza de especies fue estanque $\mathrm{A}>$ estanque $\mathrm{B}>$ estanque $\mathrm{C}$. La máxima abundancia del zoo-heleoplancton se encontró en el estanque con floraciones de cianobacterias y la mínima entre macrófitas de E. crassipes. Rotifera fue el grupo más abundante en el estanque con presencia de macrófitas. Los estadios larvales de Copepoda fueron abundantes en los estanques con materia orgánica depositada en el fondo y con dominancia de cianobacterias. A. navicula fue la población dominante en el agua libre del estanque con predominio de macrófitas. B. calyciflorus y estadios larvales de Copepoda tuvieron proporciones variables en el estanque con cianobacterias. T. decipiens fue la única población presente en el estanque con materia orgánica depositada en el fondo. Se observó un patrón de sucesión de los taxa en el estanque con importante cobertura de macrófitas acuáticas y con floraciones de cianobacterias. Las diferencias en la riqueza de especies y la baja similitud del zoo-heleoplancton entre los estanques estuvieron determinadas por la calidad del agua en relación con la presencia de macrófitas, cianobacterias, materia orgánica depositada en el fondo y peces. El análisis de regresión múltiple (stepwise) reveló que la transparencia del agua, el oxígeno disuelto y la conductividad fueron las variables ambientales que explican más de $42 \%$ de variabilidad en la abundancia de las especies dominantes.

Palabras clave: Zoo-heleoplancton, abundancia, riqueza, macrófitas acuáticas, cianobacterias, materia orgánica, peces.

\section{REFERENCES}

Aoyagui, A.S.M. \& C. Costa Bonecker. 2004. The art status studies in natural environments of South America: floodplains. Acta Scientiarum. 26:385-406.

Boltovskoy, D. 1981. Atlas del zooplancton del Atlántico Sudoccidental y métodos de trabajo con el zooplancton marino. INIDEP. Mar del Plata.Argentina.936 p.

Campos, J.R.C., F.A. Lansac-Tôha, M.A. Nunes, A.P.P. García \& F.R. Prado. 1996. Composição da comunidade Zooplanctónica de três lagoas da Ilha Porto Rico na Planicie de inundação do Alto Rio Paraná. Acta. Limnol. Bras. 8:183-194.

Carignan, R. \& J.J. Neiff. 1992. Nutrient dynamics in the floodplain ponds of the Paraná River (Argentina) dominated by Eichhornia crassipes. Biogeochem. $17: 85-121$

Casco, S., A.S.G. Poi de Neiff, R.F. Benassi \& J.J. Neiff. 2003. Crescimento de plantas flutuantes livres em diferentes condiçoes da água. IHER. Sér. Bot. 58:181-193.

Corrales de Jacobo, M.A. \& M.B. Canon Verón. 1992. Relaciones Tróficas de la Ictiofauna de Cuencas Autóctonas del Chaco Oriental. Argentina. Rev. Brasil. Biol. 55:419-437.

Erben, R., J. Lajtner, G. Klobuèar, I. Maguire, A. Luciæ \& A. Štambuk. 2002. Zooplankton reflecting the 
trophic state of the dam reservoir Modrac (Bosnia and Herzegovina). In Padisák, J. (ed.). Shallow Lakes 2002. Interantional Conference on Limnology of Shallow Lakes, Balntonfüred, Hungary. Veszprém University Press, Veszprém, Hungary. 309 p.

Frutos, S.M. 1993. Zooplancton en cuerpos de agua isleños del Bajo Paraná. Ambiente Subtropical. 3:87-121.

Frutos, S.M. 1996. Zooplancton de la laguna Turbia (Isla del Cerrito) en la confluencia de los ríos Paraná y Paraguay (Argentina). Rev. Bras. Biol. 56:569-580.

Frutos, S.M. 1998. Características estacionales del zooplancton lagunas eutrofizadas de la Cuenca del río Santa Lucía. Corrientes. Argentina. Com. Cient. y Tecnol. UNNE. Cienc.Agr. y Biol. EUDENE 6: 21-24.

Frutos, S.M. 2003. Zooplancton de Lagunas y Cursos de Agua del Sistema Iberá, p. 143-161. In Limnología del Iberá. Aspectos físicos, químicos y biológicos de las aguas. Alicia Poi de Neiff (ed.). EUDENE. Universidad Nacional del Nordeste. Corrientes, Argentina.

Fulton III, R.S. \& H.W. Paerl. 1987. Toxic and inhibitory effects of the blue-green alga Microcystis aeruginosa on herbivorous zooplankton. Jour. Plank. Res. 9:837-855.

González de Infante, A.G. 1988. El plancton de las aguas continentales. OEA. Monogr. 33, Ser. Biol. Washington, EEUU. 130 p.

Gulatti, R.D. 1990. Structural and grazing responses of zooplankton community to biomanipulation of some Dutch water bodies. Hydrobiol. 200/201: 99-118.

José de Paggi, S. \& J.C. Paggi. 1995. Determinación de la Abundancia y Biomasa Zooplanctónica, p. 315-321. In Ecosistemas de Aguas Continentales. Metodologías para su estudio. E. Lopretto \& G. Tell (eds.). Ediciones Sur. La Plata, Argentina.

José de Paggi, S. 1996. Rotifera (Monogononta) diversity in subtropical water of Argentina. Annls. Limnol. 32: 209-220.

José de Paggi, S. \& J.C. Paggi. 1998. Zooplancton de ambientes acuáticos con diferente estado trófico y salinidad. Neotrópica 44:95-106.

José de Paggi, S. \& J.C. Paggi. 2007. Zooplankton. p.229-249. In The Middle Paraná River: Limnology of a Subtropical Wetland. Springer-Verlag. Berlin, Heidelberg, Germany.
Lansac-Tôha, F.A., C. Costa Bonecker \& L.F. Machado Velho. 2004. Composition, species richness and abundance of the zooplankton community, p. 145190. In The Upper Paraná River and its Floodplain: physical aspects, ecology and conservation. S. M. Thomaz, A. A. Agostinho \& N. S. Hahn (eds.). Leiden, The Netherlands.

Lammens, E.H.R.R., R.D. Gulati, M.L. Meijer \& E. Van Donk. 1990. The first biomanipulation conference: a synthesis. Hydrobiol. 200/201:619-627.

Margalef, R. 1983. Limnología. Zooplancton. Ediciones Omega, Barcelona, España. 1010p.

Matveev, V., C.C. Martínez \& S.M. Frutos. 1989. Predatoryprey in subtropical zooplankton: water mite against cladocerans in an Argentine lake. Oecologia 79:489495.

Matveev, V.F., C.C. Martínez, S.M. Frutos \& Y. Zalocar de Domitrovic. 1992. Population control in planktonic crustaceans of a subtropical lake during seasonal succession. Arch. Hydrobiol. 124:1-18.

Mitchell, S.A. \& J.H.B. Joubert. 1986. The effect of elevated $\mathrm{pH}$ on the survival and reproduction of Brachionus calyciflorus. Aquacult. 55:215-220.

Modenutti, B.E. \& E.G. Balseiro. 1995. Muestreos y error, p. 351-359. In Ecosistemas de aguas Continentales. Metodologías para su estudio. E. Lopretto \& G. Tell (eds.). Ediciones Sur. La Plata, Argentina.

Neiff, J.J. 2001. Diversity in some tropical wetland systems of South America, p. 157-186. In B. Gopal, W.J. Junk \& J.A. Davis (eds.). Biodiversity in wetlands: assessment, function and conservation, Backhuys Publishers, Leiden, South Holland, The Netherlands.

Neiff, J.J., C.A. Patiño, A.S. Poi de Neiff, Y. Zalocar de Domitrovic \& S.M. Frutos, 2002. Response of a natural marsh to chemical and biological inputs of eutrophic waters (Saladas, Corrientes, Argentina). Asoc. Bras. Rec. Hidric.(ABRH). 7:53-62.

Nogueira, M.G. \& T. Matsumura-Tundisi. 1996. Limnologia de um sistema artificial raso (Represa do MonjolinhoSão Carlos, SP). Dinâmica das Populações planctônicas. Acta Limnol. Brasil. 8:149-168.

Pecorari, S., S. José de Paggi \& J.C. Paggi. 2006. Assesment of the Urbanization Effect on a Lake by Zooplankton. Water Res. 33:677-685.

Poi de Neiff,A.S.G. \& R. Carignan. 1997. Macroinvetebrates on Eichhornia crassipes roots in two lakes of the Paraná River floodplain. Hydrobiol. 345:185-196. 
Poi de Neiff, A.S.G., J.J. Neiff, C.A. Patiño, A.O. Ramos, J.R. Cáceres, S.M. Frutos \& M.B. Canon Verón. 1999. Estado trófico de dos lagunas en planicies anegables con áreas urbanas de la provincia de Corrientes. FACENA. 15:93-109.

Reid, J.W. 1989. The distribution of species of the genus Thermocyclops (Copepoda Cyclopoida) in the western hemisphere, with description of T. parvus, new species. Hydrobiol. 175:149-174.

Rietzler, A.C. \& E.L.G. Espíndola. 1998. Microcystis as a food source for copepods in a subtropical eutrophic reservoir. Verh. Internat. Verein. Limnol. 26:20012005 .

Rocha, M.I.A, C.W.C. Branco, G.F. Sampaio, G.A. Gômara \& R. de Filippo. 2002. Spatial and temporal variation of limnological features, Microcystis aeruginosa and zooplankton in an eutrophic reservoir (Funil Reservoir, Rio De Janeiro). Acta. Limnol. Bras. 14:73-86.

Sendacz, S. 1997. Zooplankton studies of floodplain lakes of the Upper Paraná River, São Paulo State, Brazil. Verh. Internat. Verein. Limnol. 26:621-627.
Sendacz, S, S. Caleffi \& J. Santos Soares. 2006. Zooplankton Biomass of Reservoir in Different Trophic Conditions in the State of Sâo Paulo, Brazil. Braz. J. Biol. 66:337-350.

Silva, W.M. \& T. Matsumura-Tundisi. 2005. Taxonomy, ecology, and geographical distribution of the species of the genus Thermocyclops Kieffer, 1927 (Copepoda, Cyclopoida) in Sao Paulo State, Brazil, with description of a new species. Braz. J. Biol. 65:521-531.

Sokal, R.R. \& F.J. Röhlf. 1979. Biometría. Principios y métodos estadísticos en la investigación biológica. Blume. Madrid, España. 832 p.

Starkweather, P.L. \& P.E. Kellar. 1983. Utilization of cyanobacteria by Brachionus calyciflorus: Anabaena flosaquae (NRC-44-1) as a sole or complementary food resource. Hydrobiol. 104:373-377.

Sunaga, T. \& J.R. Verani. 1997. The Fish Communities of Four Lakes. In: Limnological studies on the Rio Doce Valley Lakes. J. G. Tundizi \& Y. Saijo (eds.). São Paulo.Brazil. 528 p.

Wetzel, R.G.1975. Limnology. Washintong, D.C., USA, 743 p. 
